\title{
The Efficacy of a Web-Based Instruction and Remediation Program on Student Learning
}

\author{
Nicole Buzzetto-More and Ojiabo Ukoha \\ University of Maryland Eastern Shore, Princess Anne, MD USA
}

\author{
Nabuzzetto-more@umes.edu; oukoha@umes.edu
}

\begin{abstract}
Faculty today are challenged to meet the individualized learning needs of what is frequently a disparate student population while engaging in meaningful assessment of student learning outcomes. Learning styles and levels of preparation vary among students especially in the area of mathematics and the ability to diagnos is deficiencies and remedy needs can increase student success. Computerized homework and test management systems complete with interactive tutorials and targeted remediation exercises are being presented as a means of meeting the individual instructional needs of learners while assisting faculty through the automation of assessment. In particular, a number of studies have indicated positive student learning outcomes results when these programs are implemented into mathematics instruction (Butler \& Zerr, 2005; Kennedy, Ellis, Ojen, \& Benoit, 2007; Zerr, 2007).
\end{abstract}

The University of Maryland Eastern Shore is a Historically B lack University that primarily serves first generation, low income, and minority learners. Over the years, the number of students requiring remedial mathematics instruction has increased dramatically. In order to increase student learning outcomes success, as well as the persistence rates of students, an online homework and assessment system was implemented into all sections of remedial mathematics. Features of the system utilized include interactive tutorial exercises, an online tutoring center, an e-book, sample problems and answers, diagnostic analysis, targeted exercises, online assignments and quizzes, and an online grade book. This paper presents the findings of study that examined student satisfaction and perception of value with respect to the usage of this system as well as impact on student persistence and performance.

The results of this study were mixed and marked by high levels of neutrality; however, the findings did indicate that most students felt that the system was easy to use, a valuable learning tool, successful at having helped them to learn course concepts, and an aide that helped them to perform better on their assignments. At the same time, most student responded that they were not satisfied the system. The analysis of the student performance data noted a significant decrease in student withdrawal rates and a marked increase in pass rates for the course under consideration.

Material published as part of this publication, either on-line or in print, is copy righted by the Informing Science Institute. Permission to make digital or paper copy of part or all of these works for personal or classroom use is granted without fee provided that the copies are not made or distributed for profit or commercial advantage AND that copies 1) bear this notice in full and 2) give the full citation on the first page. It is permissible to abstract these works so long as credit is given. To copy in all other cases or to republish or to post on a server or to redistribute to lists requires specific permission and payment of a fee. Contact Publisher@InformingScience.org to request redistribution permission.
Keywords: Web-based learning, elearning, web-based mathematics instruction, online homework remediation, homework management systems, computerized assessment, e-assessment, interactive tutorials, hybrid instruction

\section{Literature Review}

The higher education landscape has changed significantly in recent years 
with an increasingly divers ifying student population. According to the President of Noel-Levitz (Noel-Levitz, 2002) by the year 2012, students enrolled in higher education will be more numerous, more diverse, and less prepared than any preceding generation.

While the importance of homework is often disputed, homework has been shown to be actively related to motivation, mastery of material, and achievement (Keith \& Benson, 1992). Further, role of feedback in homework effectiveness has been studied by Kulik and Kulik (1998) who compared the results of immediate verse delayed feedback concluding that immediate feedback was most effective regardless of the learning situation.

Because of the time involved in individualized assessment, which often conflicts with the need to deliver immediate feedback, computers are advocated as being ideally suited to quickly grading and providing feedback on large numbers of assignments (Cole \& Todd, 2003). On the whole, computer based instruction has been found to take less time than traditional instructional methods and have a positive effect on student learning in college settings (Kulik \& Kulik, 1998, Wells, 2006). Furthermore, studies have shown that the use of computerized programs to teach, assess, and assist students increases student engagement and can improve learning outcomes (Butler \& Zerr, 2005; "Can a software program improve math skills," 2005; Cole \& Todd, 2003; Shandy \& Segalla, 2005) by giving students author ity over their own learning (Cole \& Todd, 2003) and by helping students' to organize, revisit, and review assignments (Barack, 2005). In contrast, Pascarella (2004) found that the use of web-based homework systems hindered metacognitive behaviors.

Educause Center for Applied Research conducted a longitudinal study (Caruso \& Kvavik, 2005; Caruso \& Salaway, 2007; Salaway, Katz, \& Caruso, 2006) that examined student uses, perceptions, and preferences with respect to technology. The version of the study published in the fall of 2007 (Caruso \& Salaway, 2007) reported that while most students said they want to see technology incorporated in the ir courses, the majority reported that they like to see it used to a moderate degree $(59.3 \%)$ with $20.4 \%$ saying they favor extensive use, $15 \%$ preferring limited use, $2 \%$ preferring no usage, and $2.8 \%$ saying that they prefer the exclusive delivery of learning through elearning. Student experiences with course management systems (CMS) increased from $72 \%$ in 2006 to $82 \%$ in 2007 with most $(76.5 \%$ ) saying that the experience(s) were positive. Students were asked to rate the usefulness of a variety of popular CMS features. According to the findings, students overwhelmingly wanted course websites to be used for keeping track of grades, online exams and quizzes, homework submission with feedback and suggestions, and course readings and lectures.

Studies conducted by Allain and Williams (2006) us ing the WebAssign homework management system concluded that web-based assignment management systems result in a substantial increase in student time spent on course work outside of class; however, no tangible gains or losses could be noted with respect to student performance on examinations.

Echoing and furthering the finding of Allain and Williams (2006), Buzzetto-More, Hummer, and Burza (2007) examined the result of a Web-based homework management system used in basic college level accounting courses on student satisfaction and perceived value added, as well as the results on student learning outcomes. Features of the system considered included: assignment creation using algorithms to provide variations in question delivery, self-guided practice exercises, instantaneous grading with targeted feedback, learning materials, progress tracking, and a grade book. Results from the student satisfaction survey administered in conjunction with the study indicated strong student satisfaction with students reporting that the system helped them to: (a) better succeed in class; (b) rectify deficiencies; (c) better understand key course concepts; and (d) do better on assignments. In addition to the survey results, student performance data was collected and compared between groups using the system and groups of students assigned traditional 
text-based homework. When exam scores were examined, no change was indicated across groups.

Butler and Zerr (2005) examined the use of an online homework system that applied an attemptfeedback-reattempt sequence in mathematics instruction at two moderately-sized West Virginia State Universities. The results of their analys is found a high rate of student satisfaction as well as improved learning outcomes.

A study conducted at Colorado State University (Kennedy, Ellis, Ojen, and Benoit, 2007) examined the effectiveness of web-based instruction in college level pre-calculus courses. The results found that web-based instruction was effective at minimizing student concerns, increasing learner confidence, as well as with helping students remedy deficiencies.

In a study conducted by Zerr (2007) an online homework system was created and introduced into a beginning calculus class that included an attempt-feedback-reattempt sequence that was purposed to mimic the level of feedback students experience with the live presence of an instructor or tutor. The findings showed overall improvements in both student engagement and performance. Furthermore, a student satisfaction survey was distributed whose results indicated high levels of student satisfaction with the systems usefulness in helping students better understand course concepts.

Derouza and Fleming (2003) compared undergraduates who completed quizzes online with students who took traditional paper-based quizzes and found that the marks revealed that students who took the quizzes online signif icantly outperformed students who took the pencil-and-paper quizzes.

Web-based homework management and assessment systems have been shown by Palocsay and Stevens (2008) to expedite grading and assessment while providing targeted teaching to improve learning efficiency; however, after comparing traditional textbook-based homework with a webbased homework and assessment protocol, they concluded that student performance depended significantly upon teacher experience and student academic competence. Applying controls, they postulated that the delivery method did not make a significant difference in determining student success.

Minority learners, in particular African American college students, are a population that is expanding in numbers in higher education. The research shows that minority student populations are more like ly to be under-prepared for academic success (Allen, 1987; Buzzetto-More \& Ukoha, 2008; Sax, Ceja, \& Teranishi, 2001). Furthermore, B lack students who attend HBCUs have been found to be from lower socio economic backgrounds and be less prepared for college than Black students attending traditional majority institutions (Allen, 1987; Buzzetto-More \& Ukoha, 2008).

Historically B lack colleges and universities are academic institutions founded primarily for Blacks prior to 1964 which history has secured with an important place in the American system of higher education (Brown \& Yates, 2005). While, they constitute only 3 percent of U.S. colleges and universities, they enroll 28 percent of all African American college students and graduate 40 percent of the black Americans who earn doctorates or first professional degrees (Hubbard, 2006). Brown and Yates (2005) found that there has been insufficient research on Historically Black Colleges and Universities. As a result, they conclude that historically B lack colleges and universities must be studied for their contribution to both history and higher education.

\section{Background}

Founded in 1886, the University of Maryland Eastern Shore (UMES) is a historically B lack, 1890 land grant institution and a member of the University System of the State of Maryland. The student population is approximately 4000, reporting a student body that is approximately $78 \%$ Afri- 
can-American, $9.6 \%$ white, $1.4 \%$ Hispanic, and $11 \%$ international, primarily coming from the continent of Africa and/or from the Caribbean region. The gender distribution of the University is $64 \%$ female and $36 \%$ male. The average SAT score of the 2007 freshmen class was 817 , the current freshmen to sophomore retention rate is $64 \%$, and the graduation rate is $41 \%$. The average GPA of the fall 2007 freshmen class was a 2.75 and the acceptance rate for applying students is $79 \%$. As a result of liberal acceptance policy of the institution, UMES attracts a high proportion of first generation and/or underprepared students many of which require remedial instruction upon entry.

Math 101 is a remedial mathematics course offered by the University of Maryland Eastern Shore covering such concepts as order of operations, real numbers, factoring, and algebraic expressions. Students are enrolled in the course based the achievement of low scores on the mathematics portion of the Accuplacer placement test, a commercial testing product used by many U.S. institutions in order to examine the incoming math, English, and reading skills of incoming students. Over 900 students a year enroll in remedial mathematics which has historically been plagued by startlingly high fail/attrition rates with fewer than half of enrollees successfully passing the course.

In order to augment instruction and increase the success rates of students, a web-based program was introduced called MathXL. MathXL was selected after a careful consideration because it provides a learning management platform that includes an interactive self-paced homework and test manager that automates grading and provides targeted feedback. Components of the system adopted in Math 101 include:

- Interactive tutorial exercises correlated to the exercises in the textbook that regenerate algor ithmically to give students unlimited opportunity for practice and mastery. All exercises include guided solutions, sample problems, learning aids, and relevant responses when students enter incorrect answers.

- Multimedia Learning Aids including as videos and animations, as well as an e-book that are associated with the exercises.

- Homework and test manager correlated to the textbook. Homework exercises include guided solutions and link to tutorial exercises where students engage in a response, feedback, response sequence which is a typical feature for web-based learning programs.

- Shared gradebook that allows students to track and view grades automatically calculated by the system.

- Study plan for self-paced learning available in the Tutoring Center which generates a personalized plan for each student based on his or her test results linked to tutorial exercises for topics the student hasn't yet mastered (Pearson Education, 2008).

Using MathXL, Math 101 operates as a hybrid course, with the exception of major exams, all homework, out of class learning exercises, and quizzes.

\section{Methodology}

In order to examine student satisfaction and perceived value added with respect to the Math XL system, a comprehensive survey was administered during the fall and spring of 2007-2008. In total, 692 students completed the survey representing a response rate of approximately $78 \%$. Surveys were administered in person the last day of the semester after the students had completed all course work as well as the final exam.

Additionally, in order to look at the impact on student performance, longitudinal data was collected on pass/fail percentages and course retention rates. These statistics were compared in order 
to examine changes occurring following implementation; however, the researchers can only postulate whether any changes in withdrawal and pass rates are directly linked to implementation of the MathXL program.

\section{Discussion}

All respondents were enrolled in the course Math 101 (remedial mathematics) based on low scores on the mathematics portion of the Accuplacer placement test. Sixty two percent of the respondents who completed the survey were female and thirty eight percent were male which is representative of the University's larger student body. All academic majors were represented in a manner that was reflective of the University population. Seventy nine percent of the respondents were freshmen with $12 \%$ sophomore, $3 \%$ junior, and $1 \%$ senior. Eighty-five percent of the respondents were between the ages of 18-19, $10 \%$ were between $20-22,1.2 \%$ were between 23-35, and $2.1 \%$ were 26 or older. Regarding ethnic ity, $84.4 \%$ responded that they were African American, $7.5 \%$ said they were African, 2.1\% reported that they were a Caribbean Islander, $2 \%$ said they were Caucasian, . $3 \%$ said they were Asian, and $1.5 \%$ responded "other".

Participants were asked to rank themselves as a computer user with $7.7 \%$ saying that they were a novice, $32 \%$ saying that they had some experience, $42 \%$ claiming intermediate usage, and $17.6 \%$ saying that they were experts represented in Figure 1. Computer ownership was ascertained and $86.7 \%$ of respondents said that they own their own computer with $13.1 \%$ saying that they do not personally own a computer which was lower than the $97.8 \%$ rate of ownership reported by Salaway, Katz, and Caruso (2006). Internet access was prevalent with $89.5 \%$ saying that they had internet access at their home/residence. Concurrently, $82.7 \%$ of the respondents said that they go online daily with $17.3 \%$ saying that they do not visit the internet on a daily basis. Across the board, these findings are lower than the statistics that have been reported by recent ECAR studies of students attending majority serving institutions (Caruso \& Kvavik, 2005; Caruso \& Salaway, 2007; Salaway, Katz, \& Caruso, 2006).

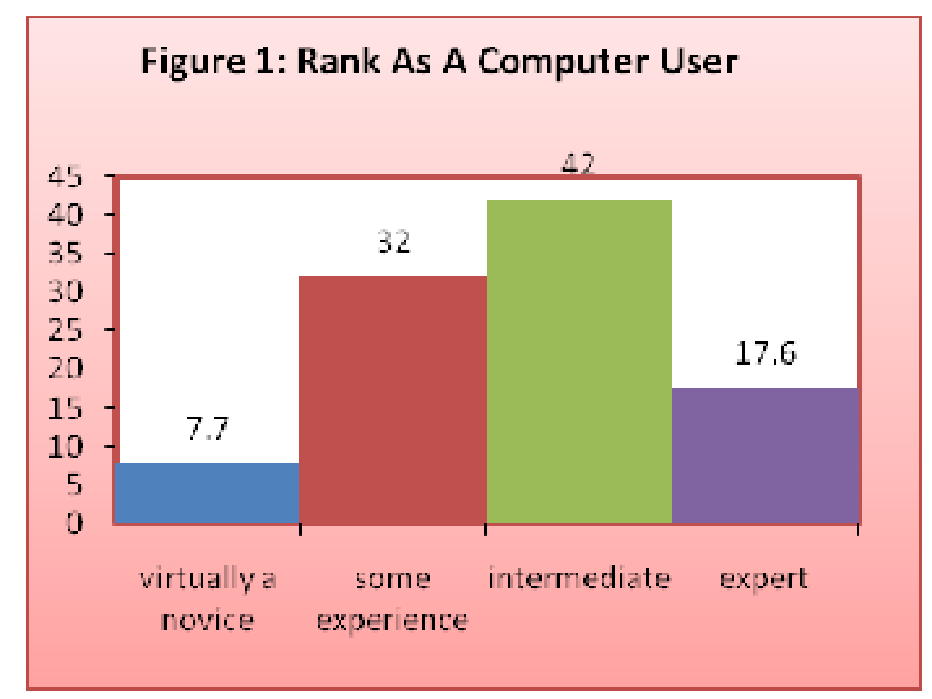

A couple of questions examined students' prior experiences and interest with e-learning. Eightysix percent of the respondents said that they have never taken a fully online course, which complements the findings of other studies conducted on HBCU students (Buzzetto-More, 2008). Additionally, when asked whether they plan to take a fully online course in the future $38.9 \%$ said yes and $61.1 \%$ said no, representing findings that were less positive than what has been reported from similar studies (Buzzetto-More, 2008). 
When asked about usage of MathXL, 85.8\% responded that they purchased a user license, $86.7 \%$ of students said that they used MathXL, and 56.1\% said that they used MathXL to prepare for the final exam. The results of the yes or no questions are depicted in Table 1.

Table 1: Student Responses to Yes of No Questions

\begin{tabular}{|c|c|c|}
\hline & Yes & No \\
\hline Did you purchase a license to use MathXL? & $85.8 \%$ & $14.2 \%$ \\
\hline Did you use MathXL? & $86.7 \%$ & $13.3 \%$ \\
\hline Do you own a computer? & $86.7 \%$ & $13.1 \%$ \\
\hline Do you have internet access at your home? & $89.5 \%$ & $10.5 \%$ \\
\hline Do you go online daily? & $82.7 \%$ & $17.3 \%$ \\
\hline Have you ever taken a fully online course? & $13.4 \%$ & $86.6 \%$ \\
\hline $\begin{array}{l}\text { Do you plan to take a fully online course in } \\
\text { the future? }\end{array}$ & $38.9 \%$ & $61.1 \%$ \\
\hline $\begin{array}{l}\text { Did you use MathXL to prepare for the final } \\
\text { exam? }\end{array}$ & $56.1 \%$ & $43.9 \%$ \\
\hline
\end{tabular}

The participants were asked where they were most likely to access MathXL with $76.4 \%$ responding that they used the program primarily at school, $12.6 \%$ saying at home, 5.3\% saying at work, and 3.5\% noting "other". These results are depicted in Figure 2.

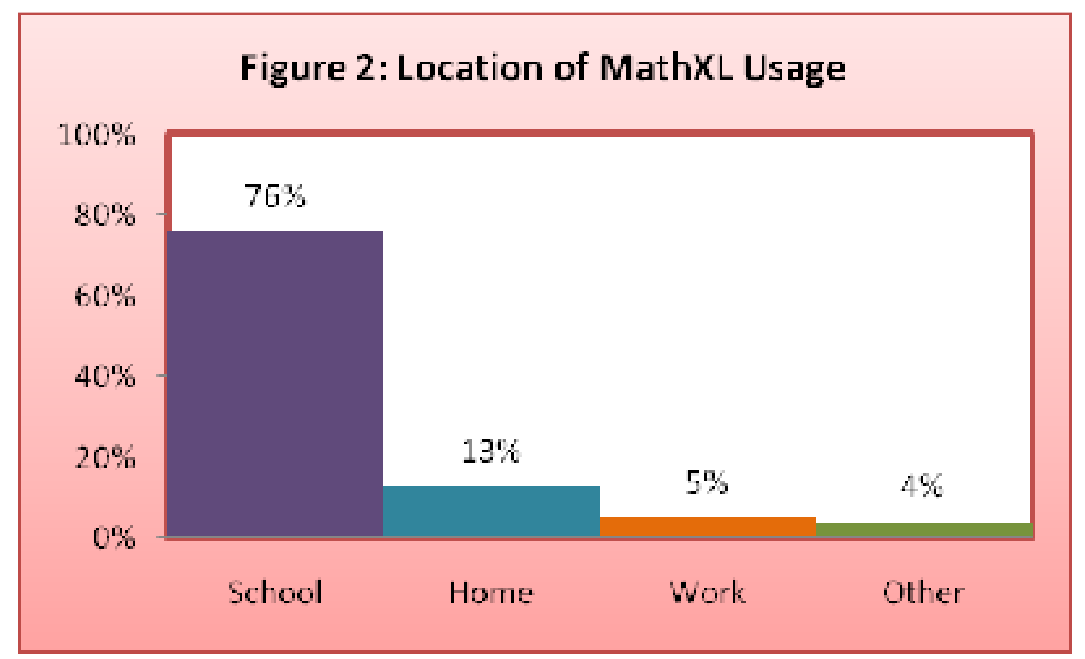

Respondents were also asked how frequently they used MathXL throughout the semester with $34.1 \%$ saying daily, $41.5 \%$ saying several times per week, $14.3 \%$ saying once a week, $1.4 \%$ saying every other week, $3.2 \%$ responding once a month, and $2.6 \%$ saying less than once a month. These results are depicted in Figure 3. 


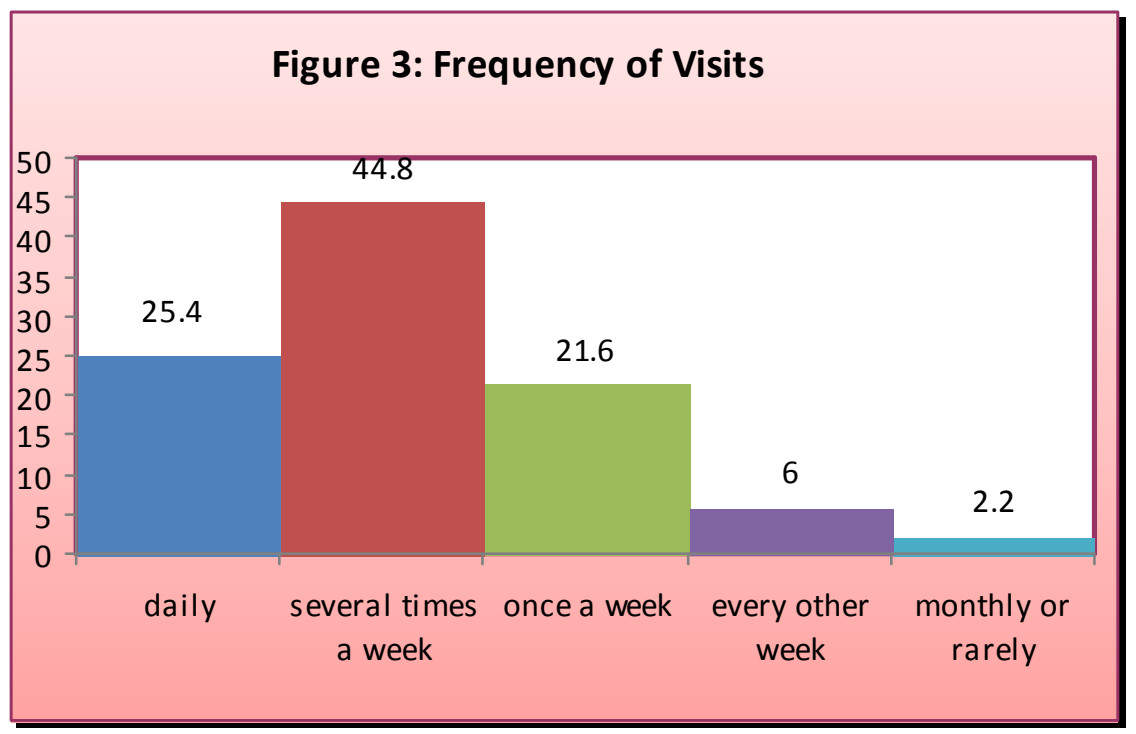

A series of five point Likert scale questions were asked where 1 equaled strongly disagree, 2 equaled disagree, 3 represented neutral or undecided, 4 equaled agree, and 5 equaled strongly agree. Perception of learning value was ascertained and $63 \%$ of respondents were in agreement/strong agreement that MathXL is a valuable learning tool, $49 \%$ in agreement/strong agreement that MathXL helped them succeed in class, and 52\% responding that MathXL enhanced their learning experience.

With respect to the learning of course concepts, $56.1 \%$ of participants in agreement that MathXL helped them better understand course concepts, $58 \%$ of the students in agreement that MathXL helped them understand what they were doing wrong, and $49.8 \%$ in agreement that MathXL helped them rectify deficiencies.

In regards to homework, 52.8\% said that using MathXL helped them do better on their assignments. Overall, $48.2 \%$ of respondents said that MathXL helped them learn math.

Approximately sixty four percent of respondents agreed/strongly agreed that MathXL was easy to use. With respect to future usage of similar systems, $48.2 \%$ said that they would like more systems like MathXL used in the ir courses.

Table 2 presents the results of the first 9 Likert scaled questions.

It is important to note, the results of the aforementioned question sets when examined on a percentage distribution basis are not as strongly positive as what is being reported in the current literature whereas students are reporting high levels of satisfaction and perception of value added (Butler \& Zerr, 2005; Buzzetto-More, Burza, \& Hummer, 2007; Kennedy, Ellis, Ojen, \& Benoit, 2007). At the same time, when means were examined, and the high levels of neutrality considered, student responses were quite positive. 
Table 2: Results of Scaled Questions 1-9

\begin{tabular}{|c|c|c|c|c|c|c|c|}
\hline & $\mathbf{S A}$ & $\mathbf{A}$ & $\mathbf{N} / \mathbf{U}$ & D & SD & Mean & STDV \\
\hline $\begin{array}{l}\text { 1. MathXL is a valuable learn- } \\
\text { ing tool. }\end{array}$ & $30.6 \%$ & $32.4 \%$ & $20.4 \%$ & $9.5 \%$ & $6.5 \%$ & 3.71 & 1.184 \\
\hline $\begin{array}{l}\text { 2. MathXL helped me succeed } \\
\text { in class. }\end{array}$ & $31.9 \%$ & $28.7 \%$ & $24 \%$ & $13.3 \%$ & $11.3 \%$ & 3.37 & 1.273 \\
\hline $\begin{array}{l}\text { 3. Using MathXL enhance my } \\
\text { learning experience. }\end{array}$ & $22.2 \%$ & $31.4 \%$ & $25 \%$ & $13.3 \%$ & $7.3 \%$ & 3.48 & 1.183 \\
\hline $\begin{array}{l}\text { 4. MathXL helped me better } \\
\text { understand course concepts. }\end{array}$ & $20.7 \%$ & $35.4 \%$ & $23.8 \%$ & $12.9 \%$ & $7.1 \%$ & 3.55 & 1.163 \\
\hline $\begin{array}{l}\text { 5. MathXL helped me under- } \\
\text { stand what I was doing wrong. }\end{array}$ & $24.1 \%$ & $34.5 \%$ & $22.1 \%$ & $11.2 \%$ & $\% 7.9 \%$ & 3.63 & 2.321 \\
\hline $\begin{array}{l}\text { 6. MathXL helped me to fix my } \\
\text { deficiencies. }\end{array}$ & $19.7 \%$ & $30.1 \%$ & $31 \%$ & $10.9 \%$ & $8.3 \%$ & 3.42 & 1.164 \\
\hline $\begin{array}{l}\text { 7. MathXL hel ped me learn } \\
\text { math. }\end{array}$ & $19.2 \%$ & $29 \%$ & $26.7 \%$ & $12.8 \%$ & $12.2 \%$ & 3.30 & 1.126 \\
\hline 8. MathXL was easy to use. & $32.6 \%$ & $31.2 \%$ & $19.1 \% \quad \mathrm{C}$ & $9.1 \%$ & $7.6 \%$ & 3.73 & 1.224 \\
\hline $\begin{array}{l}\text { 9. I woul dike see more pro- } \\
\text { grams like MathXL used in my } \\
\text { courses. }\end{array}$ & $25 \%$ & $23.2 \%$ & $25 \%$ & $10.3 \% 16$ & $6.4 \%$ & 3.30 & 1.381 \\
\hline
\end{tabular}

A series of questions were designed to look at students' perceptions of math classes. Most of the respondents $(56.2 \%)$ agreed/strongly agreed that they consider math to be a difficult subject, $43.3 \%$ said that they often have a hard time keeping up in a math classes, and $50.2 \%$ said that they are often confused in math classes. Although $70.1 \%$ agreed/strongly agreed that they are comfortable speaking up in class, a less sizable $49.2 \%$ of students said that they regularly ask questions in the classroom. Most students (68.9\%) responded that they would rather go to the instructor in person when they have a question about course content.

While most studies indicate that students want to see their courses supported by course websites (Buzzetto-More, 2008; Caruso \& Salaway, 2007), students in this study were largely ambivalent with only $45 \%$ responding that they prefer to take courses with course websites; however, a significant number (57\%) said that they liked having the ability to get math help online.

Overall satisfaction with MathXL was mixed marked by considerable neutrality and polarity whereas when asked if they were satisfied with the usage of MathXL, 38.6\% responded that they were satisfied. Results of questions 10-17 are depicted in Table 3. 
Table 3: Results of Scaled Questions 10-17

\begin{tabular}{|c|c|c|c|c|c|c|}
\hline & SA & $\mathbf{A}$ & $/ \mathbf{U}$ & SD & Mean & STDV \\
\hline $\begin{array}{l}\text { 10. Math is a difficult subject } \\
\text { for me. }\end{array}$ & $36.1 \%$ & $20.1 \%$ & $21 \%$ & $12.4 \%$ & 3.57 & 1.836 \\
\hline $\begin{array}{l}\text { 11. I often have a hard time } \\
\text { keeping up in math classes. }\end{array}$ & $22.3 \%$ & $21 \%$ & $23.4 \%$ & $17.4 \% \quad 16 \%$ & 3.16 & 1.375 \\
\hline $\begin{array}{l}\text { 12. I am often confused in math } \\
\text { classes. }\end{array}$ & $29.5 \%$ & $20.7 \%$ & $23.4 \%$ & $13.7 \% \quad 12.7 \%$ & 3.41 & 1.367 \\
\hline $\begin{array}{l}\text { 13. I am comfor table spe aking } \\
\text { up in class. }\end{array}$ & $36.6 \%$ & $33.5 \%$ & $18.3 \%$ & $7.2 \% \quad 4.4 \%$ & 3.91 & 1.109 \\
\hline $\begin{array}{l}\text { 14. I regularly asked questions } \\
\text { in class. }\end{array}$ & $21.5 \%$ & $27.8 \%$ & $29.8 \%$ & $13.9 \% \quad 7 \%$ & 3.43 & 1.172 \\
\hline $\begin{array}{l}\text { 16. I liked having the ability to } \\
\text { get math help online. }\end{array}$ & $25.3 \%$ & $31.6 \%$ & $25 \%$ & $9 \% \quad 9.1 \%$ & 3.55 & 1.218 \\
\hline $\begin{array}{l}\text { 16. I would rather go to the in- } \\
\text { structor in person when I have a } \\
\text { question about course content. }\end{array}$ & $38.2 \%$ & $30.7 \%$ & $21.3 \%$ & $5.7 \% \quad 4 \%$ & 3.93 & 1.087 \\
\hline $\begin{array}{l}\text { 17. Overall, I was satisfied with } \\
\text { MathXL. }\end{array}$ & $12.9 \%$ & $25.7 \%$ & $32.7 \%$ & $13.9 \% \quad 14.1 \%$ & 3.24 & 1.113 \\
\hline
\end{tabular}

A number of individual MathXL program components were examined. About half the students were satisfied with the online lecture notes $(51.8 \%)$, and with their role as a valuable resource $(50.2 \%)$. In addition, half $(51 \%)$ of students said that they prefer the online submission of assignments with $54.4 \%$ saying that the online submission of assignments was convenient.

Fifty-four percent of students said that they regularly used the sample problems with guided solutions and $45.1 \%$ said that the guided solutions were useful. The grade book was a popular tool with $62.2 \%$ saying that they regularly checked their grades in the grade book.

Derouza and Fleming (2003) reported positive findings from online student assessments. When asked about assessments, participating students did not indicate satisfaction with $42.2 \%$ saying that they were satisfied with the online quizzes. Furthermore, while most studies find that students consider the online delivery of quizzes convenient, this study did not concur with that general opinion with only $41 \%$ of respondents saying that the online delivery of exams was convenient. The majority of students said that they prefer to take their exams in person rather than online $(56 \%)$.

The tutoring center which develops individualized study plans for students was not widely used with only $21.9 \%$ saying that they used it and $20.6 \%$ saying that it was helpful. Additionally, very few students (18.3\%) used the electronic version of the textbook with only $31.2 \%$ saying that they would like to have e-books available in all the ir classes. The results of questions 18-31 are depicted in Table 4. 
Table 4: Results of Questions 18-31

\begin{tabular}{lllllllll}
\hline & SA & A & N/U & D & SD & Mean & STDV \\
\hline $\begin{array}{l}\text { 18. Over all, I was satisfied with } \\
\text { the online lecture notes. }\end{array}$ & $19.8 \%$ & $31.9 \%$ & $27.8 \%$ & $12.1 \%$ & $8.3 \%$ & 3.43 & 1.177 \\
\hline
\end{tabular}

19. The online lecture notes

$\begin{array}{lllllll}19.6 \% & 30.6 \% & 28.4 \% & 13.2 \% & 8.3 \% & 3.40 & 1.181\end{array}$
were a valuable resource.

20. I prefer submitting my as- $\quad \begin{array}{lllllll}24.4 \% & 26.5 \% & 21.7 \% & 12.2 \% & 15.2 \% & 3.33 & 1.367\end{array}$
signments online.

$\begin{aligned} & \text { 21. The online submission of } \\ & \text { assignments is con venient. }\end{aligned}$
$\begin{aligned} & \text { 22. Overall, I was satisfied wi th } \\ & \text { the online quizzes. }\end{aligned}$

\begin{tabular}{|c|c|c|c|c|c|c|c|}
\hline $\begin{array}{l}\text { 23. I found taking quizzes online } \\
\text { to be convenient. }\end{array}$ & $17.5 \%$ & $23.5 \%$ & $27.4 \%$ & $15.2 \%$ & $16.4 \%$ & 3.10 & 1.317 \\
\hline $\begin{array}{l}\text { 24. I would rather take my } \\
\text { quizzes in class than online. }\end{array}$ & $30.1 \%$ & $25.9 \%$ & $20.4 \%$ & $11.1 \%$ & $12.6 \%$ & 3.50 & 1.1353 \\
\hline $\begin{array}{l}\text { 25. Ifound the sample prob- } \\
\text { lems with guided solutions to be } \\
\text { useful. }\end{array}$ & $13.7 \%$ & $31.4 \%$ & $33.3 \%$ & $13.7 \%$ & $7.8 \%$ & 3.29 & 1.113 \\
\hline
\end{tabular}

\begin{tabular}{llllllll}
\hline $\begin{array}{l}\text { 26. I regularly referred to the } \\
\text { sample problems. }\end{array}$ & $25.5 \%$ & $28.4 \%$ & $27.5 \%$ & $13.7 \%$ & $4.9 \%$ & 3.56 & 1.157 \\
\hline $\begin{array}{l}\text { 27. I regularly checked my } \\
\text { grades in MathXL. }\end{array}$ & $31.2 \%$ & $31 \%$ & $25.2 \%$ & $8.7 \%$ & $3.9 \%$ & 3.77 & 1.104 \\
\end{tabular}

\begin{tabular}{l}
$\begin{array}{l}\text { 28. I used the tutoring center in } \\
\text { MathXL. }\end{array}$ \\
\hline
\end{tabular}

\begin{tabular}{lllllllll}
\hline $\begin{array}{l}\text { 29. I found the tutoring center } \\
\text { to be hel pful. }\end{array}$ & $10.3 \%$ & $10.3 \%$ & $33.3 \%$ & $28.7 \%$ & $17.2 \%$ & 2.68 & 1.186 \\
\hline
\end{tabular}

30. I regularly referred to the electronic version of the textbook.

\begin{tabular}{llllllll}
\hline $\begin{array}{l}\text { 31. I would like to have elec- } \\
\text { tronic textbooks available for all } \\
\text { of my classes. }\end{array}$ & $13.5 \%$ & $17.7 \%$ & $34.4 \%$ & $14.6 \%$ & $19.8 \%$ & 2.91 & 1.290 \\
\hline
\end{tabular}

A series of questions examined student perceptions with respect to the helpfulness of MathXL in the building of key course concepts. The results are depicted in Table 5 where they are sorted based on mean. 
Table 5: Concept Helpfulness

\begin{tabular}{lrr}
\hline & Mean & Stdv \\
\hline Real Numbers & 3.64 & 1.087 \\
\hline Order of operations & 3.63 & 1.084 \\
\hline Algebraic Expressions & 3.57 & 1.117 \\
\hline Exponents & 3.54 & 1.091 \\
\hline Factoring & 3.51 & 1.142 \\
\hline Sub Linear Equations & 3.37 & 1.103 \\
\hline Solving Inequalities & 3.33 & \\
\hline Graphing & 3.30 & 1.119 \\
\hline Quadratic Equations & 3.29 & 1.096 \\
\hline Rational Expressions & 3.22 & 1.14 \\
\hline Polynomi als & 3.18 & 1.088 \\
\hline Simplification of Rational Expressions & 3.14 & 1.184 \\
\hline
\end{tabular}

In addition to the resources available through MathXL, the department has live tutors and study sessions available. Only $28 \%$ of students said that they received tutoring services and $25 \%$ said that they attended a departmental study session. Slightly less than half of the students $(49.7 \%)$ were confident that they had passed the class. Finally, completion of remedial mathematics was not shown to increase student confidence in their mathematics abilities with only $34 \%$ saying they are more confident after having completed Math 101.

\section{Crosstabulations and ANOVAs}

To further analyze the data a number of crosstabulations were run. According to the crosstabulations, women were approximately $30 \%$ more like ly to use MathXL then males. Frequency of usage of MathXL was shown to increase satisfaction and prior experience with e-learning was not shown to impact either student usage or MathXL or student satisfaction.

Having previously taken a fully online class did not increase a student's satisfaction with MathXL. Students who consider math a difficult subject were just as likely to think MathXL is a valuable learning tool as students who do not consider math a difficult subject. Students who thought that they did not pass the class were more likely to feel that MathXL was not a helpful learning tool. Frequency of usage of MathXL positively related to the belief that MathXL is a valuable learning tool and belief that MathXL usage enhanced their learning experience.

When ANOVAs were run, whether a student was confident they had passed the class had no relationship on the belief that MathXL helped them learn math. Feelings of difficulty keeping up in math classes and the belief that math is a difficult subject was shown to relate to the belief that MathXL helped the student learn math.

\section{Analysis of Student Performance Data}

Student data was collected and while it is widely established that grades are an invalid data source, the data utilized in this study was enrollment, withdrawal, pass, and fail statistics. The MathXL program was implemented during the spring semester of 2006. Concurrently, the years 
2004-2005 represent the time prior to implementation of MathXL and the years 2006-2008 represent the time following implementation. Table 6 illustrates the student data in frequency form; however, it is important to note that analysis of student performance and retention data cannot be used to scientifically prove the effectiveness of MathXL.

Enrollment varies from semester to semester, with fall enrollments being significantly more sizable than during spring semesters. As a result, percentages were compared. According to the withdrawal data, with the exception of the spring 2006 semester which represents the semester of initial implementation and a temporary spike in withdrawal, there has been a significant decrease in student withdrawal rates whereas overtime, the withdrawal rate for Math 101 has decreased by $50 \%$. Additionally, Student pass/fail rates were examined and which the exception of the 2006 year, pass rates have increased by approximately 12

Table 6: Student Statistics

\begin{tabular}{|c|c|c|c|c|c|c|c|}
\hline Semester & $\begin{array}{l}\text { Total } \\
\text { Enrollment }\end{array}$ & Withdraw & $\begin{array}{l}\text { Withdrawl } \\
\text { Percentage }\end{array}$ & Drop & $\begin{array}{l}\text { Total } \\
\text { Remaining }\end{array}$ & $\%$ Pass & $\mid \begin{array}{l}\% \\
\text { Failed }\end{array}$ \\
\hline $2004 S$ & 241 & 27 & $11 \%$ & 58 & 195 & $54 \%$ & $46 \%$ \\
\hline $2004 \mathrm{~F}$ & 966 & 103 & $11 \%$ & 251 & 612 & $57 \%$ & $43 \%$ \\
\hline $2005 S$ & 295 & 31 & $11 \%$ & 64 & 200 & $56 \%$ & $46 \%$ \\
\hline $2005 F$ & 1151 & 109 & $10 \%$ & 272 & 770 & $44 \%$ & $56 \%$ \\
\hline $2006 S$ & 473 & 165 & $35 \%$ & 74 & 234 & $80 \%$ & $30 \%$ \\
\hline $2006 \mathrm{~F}$ & 1388 & 108 & $8 \%$ & 363 & 917 & $43 \%$ & $57 \%$ \\
\hline 20075 & 497 & 24 & $5 \%$ & 116 & 357 & $72 \%$ & $56 \%$ \\
\hline 2007F & 1220 & 56 & $5 \%$ & 309 & 855 & $65 \%$ & $35 \%$ \\
\hline $2008 S$ & 330 & 15 & $5 \%$ & 91 & 224 & $68 \%$ & $32 \%$ \\
\hline
\end{tabular}

\section{Limitations}

The greatest limitation to this study is that no scientific control had been established prior to implementation. As a result, only there was a limited availability of reliable student performance data. Furthermore, one can only postulate that the changes in withdrawal and pass rates are directly linked to implementation of the MathXL program.

An additional weakness of this study is that is focused solely on students studying remedial mathematics and did not examine the impact of such programs on non-remedial courses.

\section{Summary and Future Research}

The results of this study were mixed and marked by high levels of neutrality; however, the findings did indicate that most students felt that the system was easy to use $(63.8 \%)$, a valuable learning tool (63\%), successful at having he lped them to learn course concepts $(56 \%)$ and what they were doing wrong (58\%), and an aide that helped them to perform better on their assignments (53\%). At the same time, few students claimed satisfaction with the system (38.6\%).

The analysis of the student performance data indicated a significant decrease in student withdrawal rates and a marked increase in pass rates for the course. These statistics may be an indicator that the implementation of MathXL has increased student retention and performance in this remedial mathematics course.

The results of this study are promis ing; however, greater analysis is needed. To remedy this need, a number of actions are being taken. First, students are being tracked as they progress in their 
mathematics studies in subsequent courses which are also using the MathXL system. Additionally, more questions are being added to the instrument.

\section{References}

Allain, R., \& Williams, T. (2006). The effectiveness of online home work in an introductory science class. Journal of College Teaching, 35(6), 28-30.

Allen, W. (1987) Black college vs. white college: The fork in the road for black students. Change, 19, 2834.

Barack, L. (2005). No more lost homework. School Library Journal, 51(5), 28.

Brown, M. C., \& Yates, T. M. (2005). Toward an empirical corpus of literature on historically black colleges and universities. American Journal of Education, 112(1), 129.

Butler, M., \& Zerr, R. (2005). The use of online ho me work systems to enhance out-of-classroom student engagement. The International Journal for Technology in Mathematics Education, 12(2), 51-59.

Buzzetto-More, N., Hummer, W., \& Burza, W. (2007). Examination of a web based homework intervention program in basic accounting courses. Global Digital Business Review, 2(2), 8-16

Buzzetto-More, N., \& Ukoha, O. (2008). Student satisfaction with the usage of e-learning strategies to augment mathematics instruction. Global Digital Business Review, 3(1), 7-15.

Can a software program improve math skills? (2005). Techniques, 80(3), 14.

Caruso, J., \& Kvavik, R. (2005). Students and information technology, 2005: Convenience, connection, control and learning. EDUCAUSE Center for Applied Research. Retrieved 9/22/07 from www.educause.edu/ecarl

Caruso, J., \& Salaway, G. (2007). The ECAR study of undergraduate students and information technology, 2007. EduCause Center for Applied Research. Retrieved 9/22/07 from www.educause.edu/ecar

Cole, R., \& Todd, J. (2003). Effects of web-based multimedia ho me work with immed iate rich feedback on student learning in general che mistry. Journal of Chemical Education, 80(11), 1338.

Derouza, E., \& Fleming, M. (2003). A comparis on of in-class quizzes vs. online quizzes on student exam performance. Journal of Computing in Higher Education, 14, 121-134.

Hubbard, D. (2006). The color of our classroom, the color of our future. Academe, 92(6), 27-29.

Keith, T., \& Benson, M. (1992). Effects of manipulable influences on high school grades across five ethnic groups. Journal of Educational Research, 86(2), 85-93.

Kennedy, P., Ellis, W., Oien, J., \& Benoit, S. (2007). Mastery with meaning: Access to mathematics online. Mathematics and Computing Education, 41(2), 118-127

Kulik, J. A., \& Kulik, C. L. C. (1988). Timing of feedback and verbal learning. Review of Educational Research, 58, 79-97.

McConnell, P. J. (2000). What commun ity colleges should do to assist first-generation students. Сотmиnity College Review, 28, 75-77.

Noel-Levitz. (2002). Special analysis of national enrollment management survey. Denver, CO: NoelLevitz Centers Inc.

Palocsay, S., \& Stevens, S. (2008). A study of the effectiveness of web-based homework in teaching undergraduate business statistics. Decision Sciences Journal of Innovative Education, 6(2), 213-232. Retrieved August 28, 2008, from ProQuest Education Journals database. (Document ID: 1515422261).

Pascarella, A. M. (2004). The influence of web-based homework on quantitative problem-solving in a university physics class. Proceedings of the NARST 2004 Annual Meeting, Vancouver, BC, Canada.

Pearson Education. (2008). MathXL features. Retrieved 2/10/2009 fro m: $\underline{\text { htp://www.math xl.com/ }}$ 
Salaway, G., Katz, R., \& Caruso, J., (2006). The study of undergraduate students and information technology. EDUCAUSE Center for Applied Research, Volume 7. Retrieved 9/20/2008 from www.educause.edu/ecar/

Sax, L., Ceja, M., \& Teranishi, R. (2001). Technological preparedness among entering freshmen: The role of race, class, and gender. Journal of Educational Computing Research, 24(4), 363-383.

Shandy, H., \& Segalla, A. (2005). Student perceptions of the web-based homework program web work in moderate enrollment college algebra classes. Journal of Computers in Mathematics and Science Teaching, 24(3), 229-254.

Wells, J. (2006). Markers as sistant: A software solution for the management of the ass essment process. International Journal on E-Learning, 5(3), 439-459.

Zerr, R. (2007). A quantitative and qualitative analysis of the effectiveness of online home work in first semester calculus. The Journal of Computers in Mathematics and Science Teaching, 26(1), 55-74.

\section{Biographies}

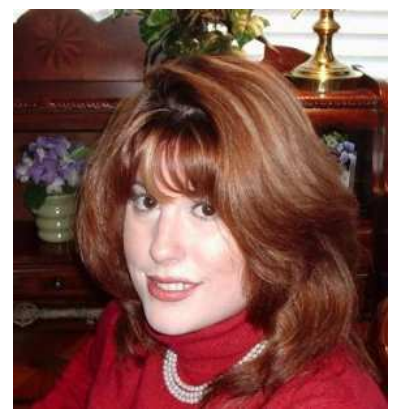

Dr. Nicole A. Buzzetto-More is an Associate Professor in the Department of Business at the University of Maryland Eastern Shore. She is also Co-Founder of the UMES Office of Instructional Technology. She received her doctorate in communication and instructional technology from Columbia University. She has served as the editor of two e-learning books published in 2007 , has contributed several book chapters, is on the editorial board of a number of journals, has authored numerous publications in referred journals, and has been recognized with awards from the American Distance Education Consortium, Global Digital Business Association, and the Informing Sc ience Institute. She is currently preparing her third book to be released in 2010 by the Informing Science Press.

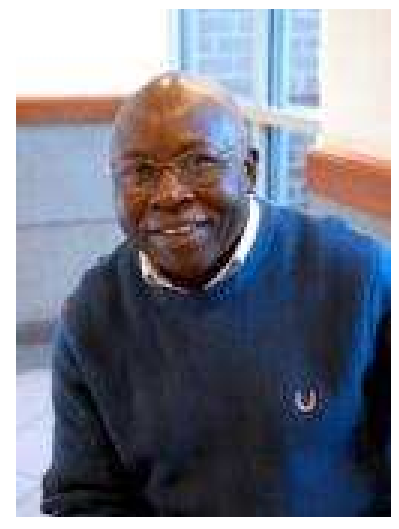

Dr. Ojiabo Ukoha is a Lecturer in the Department of Mathematics and Computer Science at the University of Maryland Eastern Shore. He received his doctorate from the University of Maryland Eastern Shore in Organizational Leadership and holds an M.B.A. from Kennesaw State College and an M.S. from Clark Atlanta University. His research interests include the infusion of technology into mathematics instruction, the retention of first generation and low-income students in higher education, and recruiting and retaining students in computer science and other STEM disciplines. 